\title{
Original article \\ Exercise motives in a sample of Brazilian university students
}

\author{
Dartagnan Pinto Guedes \\ Northern Paraná University, Brazil \\ Rosimeide Francisco Santos Legnani \\ Elto Legnani \\ Federal University of Paraná, Brazil
}

\begin{abstract}
The present study aimed to identify the exercise motives according to selected socio-demographic indicators in university students. The sample was comprised of 2,380 individuals (1,213 men and 1,167 women) aged between 18 and 35 years. The exercise motives were identified with the Portuguese-translated version of the Exercise Motivations Inventory (EMI-2). University students gave significantly greater importance to exercise for reasons identified as Disease Prevention. Factors that are less relevant in statistical language were identified in a context of motivation associated with Social Recognition and Competition. Sex, age, family economic class, experience with exercise and body weight had a significant effect on the level of importance of exercise among university students. In conclusion, the results found can contribute to the development of physical activity promotion programs and a possible reduction in the number of dropouts among university students.
\end{abstract}

Keywords: motivation, EMI-2, physical activity, young adult

Resumo- - "Motivos para a prática de exercício físico em uma amostra de universitários brasileiros." Objetivo do estudo foi identificar os motivos que podem induzir universitários a praticar exercício físico, de acordo com selecionados indicadores sociodemográficos. Amostra foi constituída por 2380 sujeitos (1213 moças e 1167 rapazes), com idades entre 18 e 35 anos. Motivos para prática de exercício físico foram identificados mediante versão traduzida do Exercise Motivations Inventory (EMI-2). Os universitários reportaram oferecer significativamente maior importância para a prática de exercício físico em motivos identificados com Prevenção de Doenças. Os fatores de menor destaque em linguagem estatística se identificaram em um contexto de motivação relacionada ao Reconhecimento Social e à Competição. Sexo, idade, classe econômica familiar, experiência de prática e status de peso corporal revelaram efeito significativo no grau de importância apontado pelos universitários para a prática de exercício físico. Concluindo, resultados encontrados poderão contribuir para delinear programas de promoção de exercício físico e provável redução dos casos de abandono entre os universitários.

Palavras-chaves: motivação, EMI-2, atividade física, adulto jovem

Resumen-"Motivos para el ejercicio físico en una muestra de estudiantes universitarios brasileños." Objetivo del estudio fue identificar los motivos que pueden inducir los estudiantes universitarios a practicar ejercicio físico, según algunos indicadores socio-demográficos. Participaron del estudio 2.380 sujetos (1.213 niñas y 1.167 niños) con edad entre 20 y 30 años. Motivos para el ejercicio físico fueron identificados por la versión traducida y adaptada del Exercise Motivations Inventory (EMI-2). Los estudiantes universitarios reportaron ofrecer significativamente mayor importancia al ejercicio físico por los motivos asociados con la Prevención de Enfermedades. Los factores menos énfasis en el lenguaje estadística se identificaron en el contexto de la motivación relacionada con el Reconocimiento Social y de la Competencia. Sexo, edad, nivel económico familiar, estado civil, experiencia de práctica y status de peso corporal revelaron efecto significativo sobre el grado de importancia indicado por los estudiantes universitarios para el ejercicio físico. En conclusión, los hallazgos pueden contribuir a diseñar programas para promover el ejercicio físico y la probable reducción de la incidencia de abandono entre los estudiantes universitarios.

Palabras claves: motivación, EMI-2, actividad física, adulto joven

\section{Introduction}

The information available in the literature emphasizes the multiple benefits of exercise to promote well-being and to minimize the risks of the onset and development of degenerative dysfunctions associated with physical inactivity (Haskell, et al., 2007; World Health Organization [WHO], 2010). In contrast, however, epidemiological surveys 
have pointed out that a small portion of the population exercises regularly (Ferreira \& Najar, 2005; Varo et al., 2003) and that, among those who begin to do so, there is an alarming number of dropouts (Anderson, 2003; Ebben \& Brudzynski, 2008).

In view of this situation, recent studies have sought to apply different theories developed in the field of psychology that could explain adherence to exercise (Deci \& Ryan, 1985). To do so, it is necessary to identify and understand the motivational factors that can cause one to exercise (Gill \& Williams, 2008). The identification of underlying reasons to exercise enables the development of actions that promote this practice and that can allow one to fully achieve one's proposed goals, thus enhancing a favorable motivational environment and, consequently, minimizing the occurrence of possible dropouts.

Clearly, sex and age stand out as important attributes in the identification of reasons associated with exercise (Andrade Bastos, Salguero, Gonzáles-Boto, \& Marquez, 2006; Brunet \& Sabiston, 2011; Chen, 1998; Kilpatrick, Herbert, \& Bartholomew, 2005; Netz \& Raviv, 2004; Quindry, Yount, O’Bryant, \& Rudisill, 2011). However, social and environmental attributes, in addition to the cultural context one is in, must regulate the selection of such reasons (Cagas, Torre, \& Manalastas, 2010; Keele, 2009; Withall, Jago, \& Fox, 2011). Moreover, the reasons to exercise can be specific, according to the population group considered. In this case, there are few studies conducted with university students and even fewer with Brazilian university students. The importance of studies performed with university students should be emphasized, considering the fact that those entering and attending universities are in an age group (1835 years) where there is a much higher risk of adopting sedentary habits, due to the need to spend several hours a day studying, resulting in a reduction in the time spent with physically active leisure (Caldas, Sallies, Lovato, \& Campbell, 1994; Keating, Guan, Piñero, \& Bridges, 2005). Therefore, experiences with exercise in the university environment can translate into a satisfactory predictor of future practice in more advanced ages in adulthood.

In this sense, assuming that the experience with exercise could also be an intrapersonal factor that might change motivational determinants aimed at this practice, the present study analyzed the possible motives to encourage university students to exercise, according to selected sociodemographic indicators.

\section{Methods}

The reference population was comprised of university students from 42 undergraduate courses of the State University of Londrina. This institution belongs to the Public Higher Education Network of the State of Paraná, including approximately 15,000 students. The sample was obtained from a probabilistic cluster sampling process, using the number of university students by sex, course, area of study and course time (morning and evening) as reference.
The sample size was established considering a $95 \%$ confidence interval, $3 \%$ sampling error and an additional $10 \%$ for losses during data collection. Taking into consideration the fact that the sampling plan involved clusters, the sampling design effect was defined at 1.5 , so that the minimum sample was initially expected to include 2,200 university students. However, the definite sample used in the treatment of information was comprised of 2,380 students (1,213 women and 1,167 men), $45 \%$ of whom were aged $\leq 19$ years, $38 \%$ between 20 and 24 years, $10 \%$ between 25 and 29 years and the remaining $7 \% \geq 30$ years.

The information about exercise motives was obtained by applying the Exercise Motivations Inventory (EMI-2), translated, adapted and validated for use in the young Brazilian population (Guedes, Legnani, \& Legnani, 2012), with additional questions about socio-demographic indicators, including self-reported body weight and height measurements.

The translated version of the EMI-2 is comprised of 44 items, grouped into ten motivational factors, representing a wide range of exercise motives defined a priori and validated with confirmatory factorial analysis resources: leisure/wellbeing, stress management, social recognition, affiliation, competition, health rehabilitation, disease prevention, body weight management, physical appearance, and physical fitness. Following its design, participants respond to the 44 items of the inventory with the heading "Personally, I practice (or could practice) physical exercise....," using the Likert scale of six points $(0=$ "completely disagree" to $5=$ "completely agree"). According to its creators (Markland \& Ingledew, 1997) and following the Self-Determination Theory (Deci \& Ryan, 1985; Hagger \& Chatzisarantis, 2008), the EMI2 enables the identification, measurement and ordering of intrinsic and extrinsic motivational factors for exercise.

Questions about socio-demographic indicators were gathered in a structured questionnaire especially developed for this study, including information about sex (female, male), age ( $\leq 19$ years, 20-24 years, 25-29 years, $\geq 30$ years), ethnicity (white, non-white), marital status (single, married/ cohabiting, separated/divorced), family nucleus (living with family, student residence, alone), paid work (does not work, works $\leq 20$ hours/week, works 20-40 hours/week), family economic class (low, middle or high, according to the directives proposed by the Brazilian Association of Market Research Companies (Associação Nacional de Empresas de Pesquisa [ABEP], 2008), including the report of household goods and level of education of family members), area of study (humanities, law and social sciences, exact and technological sciences, health and biology), year of study $\left(1^{\text {st }}\right.$ year, $2^{\text {nd }}$ year, $3^{\text {rd }}$ year, $\geq 4^{\text {th }}$ year $)$ and current experience with exercise (does not exercise, has exercised for $\leq 6$ months, has exercised for 6-24 months, has exercised for $\geq 2$ years). Based on the self-reported information about body weight and height, the body mass index (BMI) was calculated, considering the following three categories: $<25 \mathrm{~kg} / \mathrm{m}^{2}$ (normal weight); $25-30 \mathrm{~kg} / \mathrm{m}^{2}$ (overweight) and $>30 \mathrm{~kg} / \mathrm{m}^{2}$ (obesity) (WHO, 1995). 
The measuring instrument was applied to each university student individually and in only one moment by the same researcher. To achieve this, the classes randomly selected for the present study were visited by this researcher, who explained the study objectives and principles of anonymity to students. Those who signed an informed consent form received a copy of the EMI-2 with instructions for selfcompletion and information about the researcher's availability for clarifications. This instrument was completed and returned by participants and subsequently put in a ballot box. Data were collected between May and June 2008.

The statistical treatment of data was performed with the Statistical Package for the Social Sciences software (SPSS), version 20.0. Initially, the frequency distribution was tested with the Kolmogorov-Smirnov test. As the data showed a normal frequency distribution, parametric statistical methods were used with the calculation of the mean and standard deviation. Multivariate (MANOVA) and univariate variance analyses (ANOVA) were subsequently used to establish comparisons among the strata formed, where motivational factors were the dependent variables and the sociodemographic indicators selected were the independent variables, followed by Scheffe's multiple comparison test to identify specific differences. The study design was approved by the Human Research Ethics Committee of the State University of Londrina, state of Paraná (official opinion 214/07).

\section{Results}

Figure 1 shows the values of motivational factors for exercise reported by university students. When the hierarchy of mean values found for each motivational factor is considered, the most emphasized factor was characteristic of the motivational context of disease prevention (3.49 \pm 0.61 ). The factors least emphasized in statistical language were found in the motivational context of social recognition $(1.23 \pm 0.39)$ and competition $(1.61 \pm 0.61)$. The remaining motivational factors were gathered in an intermediate position in which the mean values of physical fitness $(2.95 \pm$ $0.69)$, body weight management $(2.90 \pm 0.85)$, physical appearance $(2.80 \pm 0.68)$ and stress management $(2.80 \pm 0.77)$ were significantly different from the mean values observed in leisure/well-being $(2.40 \pm 0.70)$, affiliation $(2.28 \pm 0.66)$ and health rehabilitation $(2.16 \pm 0.74)$.

The statistical information obtained with MANOVA did not point to significant differences among the strata comprising the socio-demographic indicators associated with ethnicity, marital status, family nucleus, paid work, area of study, and year of study. However, it revealed a significant effect of sex (Wilks' Lambda $=0.737 ; \mathrm{F}_{10,2369}=84.736 ; p<$ 0.001 ), age (Wilks' Lambda $=0.958 ; \mathrm{F}_{30,8973}=2.560 ; p<0.001$ ), family economic class (Wilks' Lambda $=0.957 ; \mathrm{F}_{30,8973}=2.632$; $p<0.001$ ), experience with exercise (Wilks' Lambda $=0.889$; $\mathrm{F}_{30,8954}=29.443 ; p<0.001$ ) and BMI values (Wilks' Lambda $=$ $\left.0.810 ; \mathrm{F}_{20,6948}=17.226 ; p<0.001\right)$ on the level of importance of exercise indicated by university students.

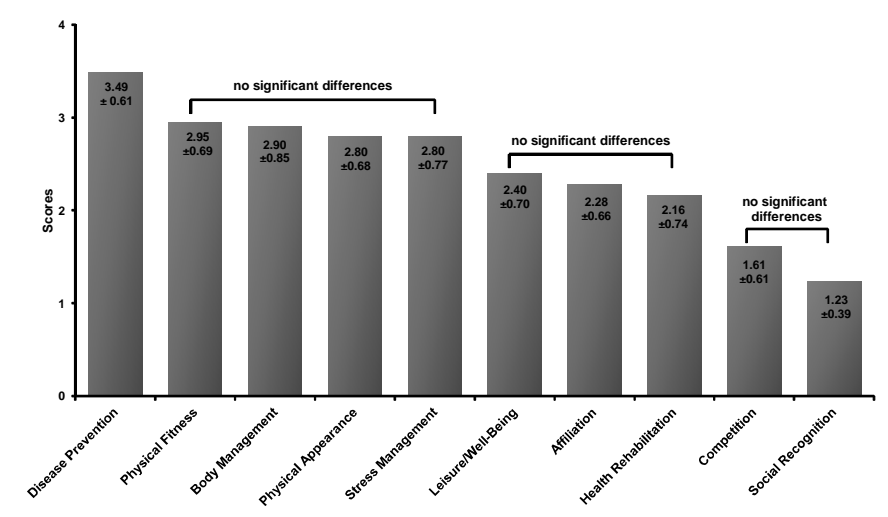

Figure 1. Motivational factors associated with exercise in university students.

Table 1 show the statistical information obtained with ANOVA, including socio-demographic indicators that had a significant effect on the motivational factors reported by university students. The results found from ANOVA indicate statistical differences between sexes in four motivational factors. Women had significantly higher mean values for body weight management $(\mathrm{F}=8.437 ; p<0.001)$ and physical appearance $(\mathrm{F}=2.896 ; p=0.046)$, whereas men had significantly higher mean values for physical fitness $(\mathrm{F}=$ 6.846; $p<0.001)$ and competition $(\mathrm{F}=10.414 ; p<0.001)$.

With regard to age, the results point to significant differences among the four motivational factors considered. The motivational factor associated with competition $(\mathrm{F}=$ 5.154; $p<0.001)$ showed significantly lower mean values with age, while those associated with disease prevention ( $\mathrm{F}$ $=8.250 ; p<0.001)$, body weight management $(\mathrm{F}=2.511 ; p=$ $0.040)$ and health rehabilitation $(\mathrm{F}=4.166 ; p=0.002)$ showed higher mean values in statistical language with age. With regard to family economic class, the results suggest that the mean values of motivational factors tended to be higher in higher economic classes. However, the differences found were only statistically identified in the case of motivational factors associated with body weight $(\mathrm{F}=3.849 ; p=0.004)$ and physical appearance $(\mathrm{F}=5.011 ; p=0.001)$ and between the mean values found in university students belonging to the highest family economic class and those found in others from the lowest family economic class.

With regard to experience with exercise, except for motivational factors associated with disease prevention, health rehabilitation and social recognition, all the remaining factors showed significant differences among the mean values observed. University students who reported having had experience with exercise for more than six months had mean values for stress management $(\mathrm{F}=4.369 ; p=0.001)$, leisure/well-being $(\mathrm{F}=11.505 ; p<0.001)$ and affiliation $(\mathrm{F}=$ 3.203; $p=0.012$ ) significantly higher than those who did not exercise or had practiced physical activity for less than six 
Table 1. Univariate variance analysis of motivational factors for exercise according to sex, age, family economic class, experience with exercise and body mass index (BMI) of university students ${ }^{1}$.

\begin{tabular}{|c|c|c|c|c|c|c|c|c|c|c|}
\hline \multirow[t]{2}{*}{ Exercise Motives } & \multicolumn{2}{|c|}{ Sex } & \multicolumn{2}{|c|}{ Age } & \multicolumn{2}{|c|}{$\begin{array}{l}\text { Family economic } \\
\text { class }\end{array}$} & \multicolumn{2}{|c|}{$\begin{array}{l}\text { Experience with } \\
\text { exercise }\end{array}$} & \multicolumn{2}{|c|}{$\begin{array}{l}\text { Body mass index } \\
\text { (BMI) }\end{array}$} \\
\hline & $\mathrm{F}$ & $\mathrm{p}$ & $\mathrm{F}$ & $\mathrm{p}$ & $\mathrm{F}$ & $p$ & $\mathrm{~F}$ & $\mathrm{p}$ & $\mathrm{F}$ & $\mathrm{p}$ \\
\hline Disease Prevention & 1.156 & $\mathrm{~ns}$ & 8.250 & $<0.001$ & 1.094 & $\mathrm{~ns}$ & 0.808 & $\mathrm{~ns}$ & 4.136 & 0.002 \\
\hline Physical Fitness & 6.846 & $<0.001$ & 0.216 & ns & 2.389 & $\mathrm{~ns}$ & 6.319 & $<0.001$ & 2.592 & $\mathrm{~ns}$ \\
\hline Weight Management & 8.437 & $<0.001$ & 2.511 & 0.040 & 3.849 & 0.004 & 10.980 & $<0.001$ & 85.299 & $<0.001$ \\
\hline Physical Appearance & 2.896 & 0.046 & 1.279 & ns & 5.011 & 0.001 & 9.357 & $<0.001$ & 6.647 & $<0.001$ \\
\hline Stress Management & 2.116 & $\mathrm{~ns}$ & 1.635 & $\mathrm{~ns}$ & 0.452 & $\mathrm{~ns}$ & 4.369 & 0.001 & 3.269 & 0.023 \\
\hline Leisure/Well-Being & 1.811 & $\mathrm{~ns}$ & 0.571 & $\mathrm{~ns}$ & 1.494 & $\mathrm{~ns}$ & 11.505 & $<0.001$ & 8.906 & $<0.001$ \\
\hline Affiliation & 2.213 & ns & 2.071 & $\mathrm{~ns}$ & 1.672 & $\mathrm{~ns}$ & 3.203 & 0.012 & 5.123 & $<0.001$ \\
\hline Health Rehabilitation & 2.351 & $\mathrm{~ns}$ & 4.166 & 0.002 & 2.140 & $\mathrm{~ns}$ & 1.256 & $\mathrm{~ns}$ & 12.474 & $<0.001$ \\
\hline Competition & 10.414 & $<0.001$ & 5.154 & 0.001 & 2.502 & $\mathrm{~ns}$ & 9.246 & $<0.001$ & 2.388 & $\mathrm{~ns}$ \\
\hline Social Recognition & 2.398 & ns & 2.013 & $\mathrm{~ns}$ & 1.879 & $\mathrm{~ns}$ & 0.715 & $\mathrm{~ns}$ & 0.851 & $\mathrm{~ns}$ \\
\hline
\end{tabular}

${ }^{1}$ F-Statistics with control for the remaining independent variables available in the table.

months. In the case of physical fitness $(\mathrm{F}=6.319 ; p<0.001)$, body weight management $(\mathrm{F}=10.980 ; p<0.001)$, physical appearance $(\mathrm{F}=9.357 ; p<0.001)$ and competition $(\mathrm{F}=9.246$; $p<0.001$ ), university students who reported not exercising had statistically higher mean values than others who did so. However, for periods equal to or longer than six months, the greater experience associated with exercising tends not to significantly change the mean values of physical fitness and competition.

The BMI of participating students also showed a significant impact on the dimensions of motivational factors for exercise, especially when those with normal weight and others with obesity were compared. University students with a BMI $>30 \mathrm{~kg} / \mathrm{m}^{2}$ had mean values of disease prevention (F $=4.136 ; \mathrm{p}=0.002)$, physical appearance $(\mathrm{F}=6.647 ; p<0.001)$ and health rehabilitation $(\mathrm{F}=12.474 ; p<0.001)$ significantly higher than those with a BMI $<25 \mathrm{~kg} / \mathrm{m}^{2}$. However, in the case of stress management $(\mathrm{F}=3.269 ; p=0.023)$, leisure/ well-being $(\mathrm{F}=8.906 ; p<0.001)$ and affiliation $(\mathrm{F}=5.123 ; p$ $<0.001$ ), students with normal weight (BMI $<25 \mathrm{~kg} / \mathrm{m}^{2}$ ) had statistically higher mean values than others with overweight $\left(25 \mathrm{~kg} / \mathrm{m}^{2}>\mathrm{BMI}>30 \mathrm{~kg} / \mathrm{m}^{2}\right)$. With regard to the factor associated with body weight management, the mean values found rose with the increase in BMI scores, indicating significant differences among the three strata compared $(\mathrm{F}=$ 85.299; $p<0.001)$.

\section{Discussion}

Motivation for exercise is a multi-dimensional psychological characteristic influenced by an individual's intrinsic aspects, such as preferences, desires and fears, and their extrinsic experiences, such as social acceptance, friendship, abilities and competences (Weinberg \& Gould,
2011). At a time when the adoption of physically active habits has been promoted in all sectors of the population (Haskell et al., 2007; WHO, 2010), it is essential that the main motives for specific population groups to exercise be evident, seeking to contribute to their adherence and minimize possible dropouts. The present study aimed to identify motivational factors associated with exercise in a representative sample of university students. This approach enables the identification of the motivational characteristics of different strata of individuals who exercise or could be exercising, making available relevant information that promotes more effective interventions aimed at encouraging exercise in the university environment.

In general, disease prevention was the main factor of motivation for exercise indicated by university students. The following factors pointed out by them were also associated with extrinsic motivation: physical fitness, body weight management, physical appearance and stress management. An important finding was the fact that leisure/well-being and affiliation, two relevant factors associated with intrinsic motivation, ranked significantly lower than other factors traditionally associated with extrinsic motivation and similarly to health rehabilitation. Factors associated with competition and social recognition were ranked as attributes with a lower motivational level by university students. When the reasons to exercise were analyzed by sex, women were found to attribute a significantly higher level of importance to body weight management and physical appearance, whereas men considered the motives associated with physical fitness and competition to be more important. Evidence available in the literature confirms the trend of females selecting aesthetical reasons to exercise more frequently than men, who tended to value attributes associated with challenge and personal competence (Andrade Bastos et al., 2006; Brunet \& Sabiston, 2011; Cagas et al., 2010; Kilpatrick et al., 2005; Wilson \& 
Rodgers, 2002). This is an interesting finding, as it suggests the occurrence of similarities in the level of importance given by women and men to the attributes associated with intrinsic motivation and the existence of significant differences in the attributes associated with extrinsic motivation between sexes.

With regard to age, although the mean values found for competition were comparatively lower than the remaining motivational factors, university students aged $<20$ years attributed a significantly higher importance to this factor than others aged $\geq 30$ years, thus confirming the typical predisposition of younger individuals to face challenges and test their personal competence (Yan \& Mccullagh, 2004). University students aged $\geq 30$ years reported they were significantly more motivated to exercise for reasons associated with disease prevention, body weight management and health rehabilitation than younger students. Similar results were identified in previous studies (Andrade Bastos et al., 2011; Brunet \& Sabiston, 2011; Netz \& Raviv, 2004) and they can be justified by the concern for health inherent in the advance of age.

It is hypothesized that the theoretical model of adherence to exercise associated with the belief in health can provide a plausible explanation for the significant differences observed in this context. In this case, even when considering that the harm to health caused by physical inactivity can be present from an early age, individuals only tend to adopt concepts of health promotion and disease prevention/ rehabilitation with regard to exercise when they grow older, as they perceive the threat of and their vulnerability to diseases.

Previous studies have also pointed to favorable evidence of the possible relationship between economic class and motivational factors for exercise (Withall et al., 2011). In the present study, university students belonging to higher family economic classes were significantly more motivated to exercise than less privileged students, as observed through body weight management and physical appearance. In this case, in agreement with the results found in studies with adolescents (Ingledew \& Sullivan, 2002), it is assumed that, due to the context in which university students are found, those with a higher family economic level would be more concerned about aesthetical reasons to exercise, causing them to seek to achieve a slim body and a body image that meets the aesthetic standards imposed by modern society. Among the university students who reported exercising, the level of motivation associated with stress management, leisure/well-being and affiliation became significantly higher with the increase in the level of experience with exercise. The level of motivation associated with disease prevention, health rehabilitation and social recognition did not have any significant impact on the intention to exercise and length of experience with exercise. However, university students who reported not exercising or exercising for less than six months attributed significantly less importance to stress management, leisure/well-being and affiliation and, inversely, significantly more importance to body weight management and physical appearance than those with longer experience with exercise.

These results are consistent with the findings from other studies that reported different motivations for adherence to and maintenance of exercise (Frederick-Recascino \& Schuster-Smith, 2003; Malby \& Day, 2001). In the present study, although rewards associated with extrinsic motivation are defined as key aspects in the initial stages of adherence to exercise, theoretical and empirical pieces of evidence point to the importance of rewards related to intrinsic motivation for the maintenance of such practice (Ryan et al., 1997). Likewise, beginners are usually more oriented towards results, unlike those who are more experienced and report their preference for reasons associated with subjective aspects of exercise, such as pleasure, well-being, satisfaction and the opportunity to be with friends (Buckworth \& Dishman, 2002). A possible reason for this behavior could be associated with the fact of individuals who have begun exercising more recently not being yet aware of the benefits that exercising can provide to the psycho-social dimension. However, from the moment that these benefits are perceived, they begin to act as a powerful incentive to continue exercising.

With regard to the impact that the BMI, an indicator associated with overweight and obesity, can have on motivational factors for exercise, the level of motivation of the two factors related to aesthetics, body weight management and physical appearance, rose significantly according to increasing values of body weight, especially among women. This observation confirms the results of previous studies with regard to the concern and dissatisfaction with one's body image expressed by young adults with overweight and obesity (Ingledew \& Sullivan, 2002; Kim \& Lee, 2011), thus having repercussions on the level of importance attributed to aesthetical reasons to exercise.

Additionally, health reasons were more valued by university students with overweight. Those with a BMI > 30 $\mathrm{kg} / \mathrm{m}^{2}$ reported they were more motivated to exercise due to factors associated with disease prevention and health rehabilitation than others with a BMI $<25 \mathrm{~kg} / \mathrm{m}^{2}$. These findings show that obese students have a clear perception of the risks of excess weight to health and, consequently, they can adhere to exercise motivated by this context. In contrast, types of behavior regulated by the intrinsic dimensions of motivation, represented by factors associated with stress management, leisure/well-being and affiliation, were more significant motivational agents for university students with a normal weight to exercise than others with overweight or obesity. The findings of this study can be interpreted in the light of the self-determination theory (Deci \& Ryan, 1985; Hagger \& Chatzisarantis, 2008). In this case, when intrinsically motivated, it seems that physically active individuals tend to become involved with exercise for the pleasure and satisfaction inherent in their own practice, when in fact this practice meets their psychological needs for autonomy, competence and self-realization. When extrinsically motivated, individuals seek to become involved with 
exercise primarily to meet the externally imposed demands or to obtain rewards that are attributed through their practice. Thus, different motivational approaches can lead to distinct cognitive, emotional and behavioral consequences.

A longitudinal follow-up has shown that reasons identified in intrinsic dimensions, rather than extrinsic ones, are more effective and likely to be maintained for longer (Vierling, Standage, \& Treasure, 2007). Thus, individuals intrinsically motivated to exercise should be more likely to adhere to this practice than those extrinsically motivated. In addition, experimental observations revealed that many individuals begin exercising due to weight loss and health reasons; however, few of them continue to exercise regularly unless they find pleasure and satisfaction in their practice (Weinberg \& Gould, 2011).

The present study had some limitations that must be taken into consideration. In this sense, it should be emphasized that the information about motivational factors for exercise were self-reported. However, self-reporting is a procedure used in studies with these characteristics and the most viable way to perform large scale surveys. On the other hand, the sample size enables possible inaccuracy in the estimates calculated to be somewhat minimized. Moreover, the cross-sectional approach to data can limit the establishment of associations without considering the possibility of inverse causality.

In conclusion, the evidence found in the present study pointed to specific differences in motivational factors for exercise according to sex, age, family economic class, experience with exercise and BMI values of university students. Nonetheless, an important result that stands out is the university students' tendency to identify factors associated with the external dimensions of motivation (disease prevention, physical fitness, body weight management, physical appearance, and stress management) as key motivational factors for exercise. In this sense, based on the assumption of the self-determination theory, the present findings suggest that the students analyzed in this study should have more difficulty in adhering to exercise in a more effective and lasting way, as they prioritize factors associated with extrinsic motivation. The results observed in this study can be particularly useful for professionals who work in the areas of physical education and public health, as they provide resources that help to develop physical exercise programs in the university environment, including actions that can increase the level of motivation according to the EMI-2 dimensions.

\section{References}

Anderson, C.B. (2003). When more is better: number of motives and reasons for quitting as correlates of physical activity in women. Health Education Research, 18, 525-537.

Andrade Bastos, A., Salguero, A., Gonzáles-Boto, R., \& Marquez, S. (2006). Motives for participation in physical activity by Brazilian adults. Perceptual and Motor Skills, 102, 358-367. Associação Brasileira de Empresas de Pesquisa (2008). Critério
Padrão de Classificação Econômica Brasil/2008. São Paulo: ABEP.

Brunet, J., \& Sabiston, C.M. (2011). Exploring motivation for physical activity across the adult lifespan. Psychology of Sport and Exercise, 12, 99-105.

Buckworth, J., \& Dishman, R.K. (2002). Exercise Psychology. Champaign: Human Kinetics.

Cagas, J.Y.; Torre, B., \& Manalastas, E.J. (2010). Why do Filipinos exercise? Exploring motives from the perspective of Filipinos youth. In: Chia M, Wang J, Balasekaran G, Chatzisarantis N (Eds.). Proceedings of the III International Conference of Physical Education and Sports Science (pp.243-248). Singapore: National Institute of Education.

Caldas, K.J.; Sallies, J.F.; Lovato, C.Y., \& Campbell, J. (1994). Physical activity and its determinants before and after college graduation. Medicine, Exercise, Nutrition and Health, 3, 323334.

Chen, W. (1998). Chinese and American college students' motives for participation in physical activities. Perceptual and Motor Skills, 87, 1463-1470.

Deci, E.L., \& Ryan, R.M. (1985). Intrinsic Motivation and SelfDetermination in Human Behavior. New York: Plenum.

Ebben, W., \& Brudzynski, L. (2008). Motivations and barriers to exercise among college students. Journal of Exercise Physiology, $11,1-11$.

Ferreira, M.S., \& Najar, A.L. (2005). Programas e campanhas de promoção da atividade física. Ciência e Saúde Coletiva, 10, 207-219.

Frederick-Recascino, C.M., \& Schuster-Smith, H. (2003). Competition and intrinsic motivation in physical activity: a comparison of two groups. Journal of Sport Behavior, 26, 240-254.

Gill, D.L., \& Williams, L. (2008). Psychological Dynamics of Sport and Exercise (3rd Edition). Champaign: Human Kinetics.

Guedes, D.P., Legnani, R.F.S.L., \& Legnani, E. (2012). Propriedades psicométricas da versão brasileira do Exercise Motivations Inventory (EMI-2). Motriz, 18(4), 667-677.

Hagger, M.S., \& Chatzisarantis, N.L.D. (2008). Self-determination theory and the psychology of exercise. International Review of Sport and Exercise Psychology, 1, 79-103.

Haskell, W.; Lee, I.M.; Pate, R.; Powell, K.; Blair, S., \& Franklin, B. (2007). Physical activity and public health: updated recommendation for adults from the American College of Sports Medicine and the American Heart Association. Circulation, 116, 1081-1093.

Ingledew, D.K., \& Sullivan, G. (2002). Effects of body mass and body image on exercise motives in adolescence. Psychology of Sport and Exercise, 3, 323-338.

Keating, X.D.; Guan, X.D.; Piñero, J.C., \& Bridges, D.M. (2005). A meta-analysis of college students' physical activity behaviors. Journal of American College Health, 54(2), 116125.

Keele, R. (2009). Development of the exercise motivation questionnaire with Mexican American adults. Journal of Nursing Measurement, 17(3), 183-194.

Kilpatrick, M.; Herbert, M., \& Bartholomew, J. (2005). College students' motivation for physical activity: differentiating men's and women's motives for sport participation and exercise. Journal of American College Health, 54, 87-94.

Kim, Y.H., \& Lee, H.K. (2011). Obese adolescents' physical activity and its related motivational variables. International Journal of Sport and Society, 2, 47-54.

Malby, J., \& Day, L. (2001). The relationship between exercise motives and psychological well-being. Journal of Psychology, 
$135,651-660$.

Markland, D., \& Ingledew, D.K. (1997). The measurement of exercise motives: factorial validity and invariance across gender of a revised Exercise Motivations Inventory. British Journal of Health Psychology, 2, 361-376.

Netz, Y., \& Raviv, S. (2004). Age differences in motivational orientation toward physical activity: an application of social cognitive theory. Journal of Psychology, 138, 35-48.

Quindry, J.C.; Yount, D.; O’Bryant, H., \& Rudisill. M.E. (2011). Exercise engagement is differentially motivated by agedependent factors. American Journal of Health Behavior, 35(3), 334-345.

Ryan, R.M.; Frederick, C.M.; Lepes, D.; Rubio, N., \& Sheldon, K.M. (1997). Intrinsic motivation and exercise adherence. International Journal of Sport Psychology, 28, 335-354.

Varo, J.J.; Martínes-Gonzáles, M.A.; Irala-Estévez, J.; Kearney, J.; Gibney, M., \& Martínez, J.A. (2003). Distribution and determinants of sedentary lifestyles in the European Union. International Journal of Epidemiology, 32, 138-146.

Vierling, K.K.; Standage, M., \& Treasure, D.C. (2007). Predicting attitudes and physical activity in an at-risk minority youth sample: a test of self-determination theory. Psychology of Sport and Exercise, 8, 795-817.

Weinberg, R., \& Gould, D. (2011). Foundations of Sport and Exercise Psychology (5th Edition). Champaign: Human Kinetics.

Wilson, P.M., \& Rodgers, W.M. (2002). The relationship between exercise motives and physical self-esteem in female exercise participants: an application of self-determination theory. Journal of Applied Biobehavioral Research, 7, 30-43.

Withall, J.; Jago, R., \& Fox, K.R. (2011). Why some do but most don't. Barriers and enablers to engaging low-income groups in physical activity programmers: a mixed methods study. $B M C$ Public Health, 11, 507.

World Health Organization [WHO] (1995). Physical Status: The Use and Interpretation of Anthropometry. Report of a WHO Expert Committee. WHO Technical Report Series, 854, 1-452.

World Health Organization [WHO] (2010). Global Recommendations on Physical Activity for Health. Geneva: World Health Organization.

Yan, J.H., \& McCullagh, P.J. (2004). Cultural influence on youth's motivation of participation in physical activity. Journal of Sport Behavior, 27, 378-390.

\section{Authors' note}

Dartagnan Pinto Guedes is affiliated with the Research Center in Health Sciences, Northern Parana University, Brazil.

Rosimeide Francisco Santos Legnani and Elto Legnani are affiliated with the Research Center in Exercise and Sport, Federal University of Paraná, Brazil.

\section{Acknowledgements}

Funding: The primary author is supported by Brazilian National Board for Scientific and Technological Development (CNPq) (Protocol no. 302347/2010-0).
This study was presented as part of an invited lecture at the $8^{\text {th }}$ International Congress of Physical Education and Human Movement and $14^{\text {th }}$ Symposium Paulista Physical Education.

\section{Correspondence}

Dartagnan Pinto Guedes, Rua Ildefonso Werner 177, Condomínio Royal Golf, 86055-545, Londrina, Paraná, Brazil.

E-mail: darta@ sercomtel.com.br

Declaration of Conflicting Interests: The authors declared no conflicts of interest with respect to the research, authorship, and/ or publication of this article.

Muscript received on March 30, 2013

Manuscript accepted on May 10, 2013 